\title{
The Rise of Nazism and Militarism
}

\author{
Anping Yang
}

\begin{abstract}
The essay discusses the rise of Nazism and Militarism during interwar Germany and Japan. It compares the similarities and differences that existed in the social, economic, and political environment of the two countries. The essay approaches the topic by analyzing the cause and effect of economic depression, social upheaval, and unique political propaganda. The paper intends to provide information about circumstances when extremism revives, and thus to avoid similar conditions in the future.
\end{abstract}

Index Terms - Economic Depression; Militarism; Nazism; World War.

\section{INTRODUCTION}

On November 21, 1945, twenty-two Nazi military and political leaders were investigated in the Nuremberg Trials in Germany. Twenty-four major war criminals and seven organizations were accused of war crimes by the tribunal, and ten defendants were executed after the adjudication. Six months later, the International Military Tribunal for the Far East (IMTFE) convened to prosecute defendants who were prominent members of the Empire of Japan. The tribunal accused the defendants of participating in a joint conspiracy to plan and initiate wars and commit crimes against humanity. Behind these final trials of justice were the fascists' unrealistic illusions - now piled up corpses of millions of civilians and soldiers. Indeed, the series of conflicts provoked by Nazi Germany and fanatic Japanese militarists caused more than 60 million casualties in many different countries. The reasons for the emergence of these extreme ideologies in both Germany and Japan coincided in certain aspects, reflecting the influence of instability on people's general views, which also impacted government and politics. Importantly, the process by which Japanese militarism and Nazism became powerful shared many common reasons including a global economic recession as well as the surge of nationalist thoughts and movements. In the following paper, I will show that whereas in Japan militarism interacted with monarchism in a relatively stable political environment, in Germany Nazism began autocratically with the influence of domestic unrest; yet both led by their dependency on foreign investment which created economic fragility and government bankruptcy. In order to do so, this paper will analyze the similarities and the differences between the rise of extreme ideologies in Germany and Japan with regard to each country's economic, social, and political conditions on the eve of World War II.

\section{ECONOMIC RECESSION IN PREWAR GERMANY AND JAPAN}

As is often the case, economic uncertainty drives social and political moods. Economic bases determine the distribution of social divisions, that is to say, people are divided into groups due to their different positions and relations by means of production. As a result, recessions and depression often serve as the chief cause of cycles of upheaval, instability, and political change. For this reason, in order to understand the differences between the rise of extreme ideologies in both countries it is necessary to begin by looking at their respective economic histories. Germany and Japan's dependence on foreign investments created economically fragile conditions, contributing to their inability to respond to external financial shocks, and inducing government bankruptcy and recession. The primary cause, somehow, was the misguided measures taken by the government based on inaccurate predictions before World War 1.

Germany was based on the gold standard like other countries in 1900 that is, "citizens could exchange banknotes for gold coins with the same value." [1]. In August 1914, the first measure introduced by the German Reichstag relieved the Reichsbank, the central national bank, of the requirement that Germany conduct a war in support of its Austrian ally. The Reichsbank paid for the war on credit, and a warbond drive was held with particular banks engaged in the sale of war bonds [1]. When a new government was established, "it had lost more than 10 percent of its tax base while owing 98 billion marks in war bonds to its people" [1].

Nonetheless, the economic recessions were directly precipitated by the Treaty of Versailles on the base of mismanaged war bonds. Signed in 1919, the treaty symbolized a plundering by the victorious nations over the industrial and natural resources of the defeated nation. Article 45 , for instance, ordered a "compensation for the destruction of the coalmines situated in the Saar Basin" [2]. Heavy industry areas such as the Saar Basin provided crucial raw materials, power, and technical equipment to all sectors of Germany's national economy and industry. They functioned to provide the raw materials that fostered industrial production. The scale and level of a country's heavy industry were important symbols that reflected national power. Germany, from this point in time, had lost its largest heavy industry area for coal and steel production, bringing its economic progression to a complete stop and even depression.

As Article 231 of the treaty stipulated, Germany and her allies were responsible for all the lost and damages [2]. By 
forcing Germans to accept the clause that was often referred to as the war guilt clause, Allied Powers thus demanded Germany to pay for the amount of damage caused by their war actions a 132-billion-mark indemnity. The London Schedule of Payment, as a complement, further clarified and specified the reparation mechanism for Germany. The German debt will be divided into three bond sequences, named A, B, and C. For these, the A Bonds, which amounted to 12 billion marks of gold, contained an unpaid balance of 20 billion interims, while the B Bonds accumulated to 38 billion [3]. The schedule certainly brought problems to the German economy since its inception as Germany claimed later in the summer of 1921 to the end of 1922 that the reparations were causing deflation in the country. The government was forced to print more money, which resulted in the inflation of prices and a massive increase in borrowing. Governors at the federal, state, and local level borrowed money to finance continued operations and to retire old debt [1]. The need for new banknotes had become so immense that "30 paper mills and 150 printing plants were used exclusively to print money" [1].

The Entente powers, which includes France, United Kingdom, and Russia, disputed the new reparation plans of Germany. The British argued that since Germany had effectively damaged its currency, a complete four suspension on all reparations payments was given to encourage financial rehabilitation. The French, however, insisted on the acquisition of lands, state forests, customs posts, and anything that guaranteed the resumption of reparations [3]. The Entente forces and Germany met in Paris on January 2, 1923, to come up with a new plan. The plan ultimately failed and became the direct cause that led to the occupation of Ruhr by France, Belgium, and Italy. French, Belgian, and Italian engineers entered Germany's Ruhr area on January 11 to collect the coal, supported by contingents of French and Belgian armies. The occupation operation brought participants considerable benefits while further damaging Germany's crumbling economy: "the net Ruhr receipts amounted to nearly 900 million gold marks" [3]. Germany, however, still had to pay for corresponding expenses of the passive resistance movement in the region, which added another burden to Germany's weary economy and made hyperinflation inevitable.

Along with the Treaty of Versailles, the influx of foreign investments also contributed to Germany's economic troubles. The crisis resulted from the collision of the world economy's instability and the prevailing theories of financial decision-makers who tried to resolve the imbalances. Some of the most significant factors for allowing resumed capital flow throughout the postwar decade was the dominant economic theory of the gold standard [3]. If, for example, a stimulus to a nation reduced its exportation, the result would be a gold outflow, which would raise the exporting region's prices. Nonetheless, since World War I, policymakers could not think of any better means of reorganizing the world economy than maintaining the gold standard - that is, fixing one price and ensuring all the others were flexible. Throughout this time, the United States accepted the role of the leading foreign lenders and redirected large sums of funds to Germany throughout the 1920s [3]. The loans were intended to aid Germany in retaining its currency's gold value, as well as to allow the Weimar government to pay the reparations and to experience a rise in consumption [3]. However, economic problems in the 1920s struck Germany and the United States: both housing and the stock market collapsed. As the crisis extended to various regions, foreign trading declined, but prices did not drop as much as anticipated to stabilize the economies.

When all of the international and domestic predicaments added up, the central government was unable to respond with any fiscal stimulus to fix hyperinflation in 1930. Prices in Germany, including food supplies, were beginning to skyrocket. A loaf of bread worth 0.5 marks in December 1918, 4 marks in December 1921, 163 marks in December 1922, and 250 marks in January 1923, eventually reached a price of 201,000,000,000 marks in November of 1923. One pair of shoes worth 12 marks in standard time, for instance, was worth 32,000,000,000,000 marks in November of 1923, the peak of hyperinflation in the area of Berlin [4]. The entire society went into chaos and disorder. A journalist captured his memory of these conditions in the following words:

"Bartering became more and more widespread; a haircut cost a couple of eggs. A student I knew [...] had sold his gallery ticket [...] at the State Opera for one dollar to an American; he could live on that money quite well for a whole week. The most dramatic changes in Berlin's outward appearance were the masses of beggars in the streets" [4].

People who owned small businesses were affected the most. A memory of Karl Nagerl, who was a schoolboy in 1923, described a scene where he and his friends were playing football when one of his friends went to buy some bread rolls with 500,000 marks. His friend, turned out, only returned with one, as the roll costs 400,000 marks [4]. Hyperinflation had a traumatic effect on society; people were now struggling to survive. People became millionaires but were still poor; parents still did not own enough to feed all their children; factories and schools were shut down. Men and women started to question the government's effort in resolving the crisis as the Weimar Republic was on the edge of collapsing, which in turn gave the Nazi party the opportune context in which to seize power.

In a relatively similar manner, Japan was relying upon imports and aid during the same period, which meant that its economy needed to adjust to the global economic environment. The lack of natural resources made Japan extremely passive when reacting to turbulence. The island owns "negligible mineral resources, fish, note, with virtually no natural energy resources" [5]. In an estimation of 2011, only $12.5 \%$ of its land area is agricultural land, $11.7 \%$ of arable land, $0.8 \%$ for permanent crops: $0.8 \%$, and no land for permanent pasture [5]. There are many inactive and some active volcanoes, along with tsunamis and typhoons, around 1,500 seismic events per year usually tremors, but occasionally severe earthquakes. The production of crude oil was at zero barrels a day [5].

By examining the Japanese interwar economic crisis, itself, it can be concluded that western trading barriers and internal problems both contributed to the country's problems. The first subperiod from 1914 to 1919 was an economic boom 
with rapid growth. Further problems occurred in 1922; bank runs started across the country, initiated by the bankruptcy of the Ishii Corporation, "a lumber company engaged in speculative activities" [6]. It went bankrupt in late February 1922, fueling a bank run in Japan's Kochi Prefecture including the southwestern Kansai area. Then, the bank expanded across the country from October to December 1922, from Kyushu to Kanto. The first stage of the financial collapse in Japan started during the interwar period in 1927. The Japanese had already begun to suffer from the aftermath and instability of the economic boom of World War 1. The Cabinet intended to issue an emergency ordinance requiring the Bank of Japan to transfer relief funds to the Bank of Taiwan and to compensate up to a total of 200 million yen for any losses caused by its actions. The Privy Council, which granted the power to enact the emergency order, politized and rejected the Cabinet's request on 17 April [6]. Cabinet Wakatsuki was dismissed, and financial instability then spread throughout the country. After the Showa Financial Crisis, the Japanese economy got short-term relief but then fell into the Showa Depression in 1930 and 1931 again as a consequence of a series of mismanagement and foreign interference. As a result, "the GNP deflator dropped from $13.6 \%$ to $-10.3 \%$ within 17 years;" thus devastating the Japanese economy [6].

Trading barriers of resources set up in the 1900s intensified conflicts among Japan and the western countries and therefore functioned as another catalyst for the two financial crises in Japan. Since the Great Depression of 1929, trading controls spread worldwide, particularly towards Japan, a country from the far east. In the United States, for example, Congress enacted the Smoot-Hawley Act in 1930 in reaction to demands from the agriculture and other light industry industries, mainly aimed at increasing tariffs on goods in both fields [7]. The United Kingdom, similarly, adopted a decree called General Tariff in 1932 [7]. Besides the United Kingdom and the United States, Germany, Italy, Spain, and France also added tariffs on the products. Italy's tariff increased by $250 \%$ from 1913 to the 1930s [7]. Yen devaluation and dramatic extension of exports to Japan had taken place in this unfavorable trading environment, and the United Kingdom and its colonies increased trade restrictions on Japanese products, especially cotton fabrics, since the 1930s. Domestic products gradually tried to replace the importation of goods in modern industries. Yet the quality of domestic products was still inadequate to compete with goods from more developed areas. For instance, Okura and Teranishi pointed out that "even after the domestic production ratios had increased in the machinery industry, larger and more sophisticated models continued to be imported from Western countries" [7]. Consequently, outlets for the growth of export markets in industrial products, for instance, chemicals were limited to colonies and semicolonies.

The persistent trading deficit between Japan and the West that led to the crisis of the Japanese economy was caused by the strong domestic consumer rates compared to international markets [7]. Following the consumer price index of Japan, the United Kingdom, and the United States, markets in all three countries stayed together at steady rates until 1913, increased after the First World War, and then plunged, yet to a smaller degree in Japan [6]. When the United Kingdom first agreed in September 1931 to quit the gold standard, foreign investors had predicted that Japan would finally be forced to follow along. The move to sell yen in exchange for the dollars led to a significant capital outflow. Nonetheless, when the country sold the yen, the exchange rate momentarily fell from equilibrium, $\$ 49,845$ to just $\$ 20$ in November 1932, an exchange rate where the currency was a dollar and 44 cents against the pound sterling [6]. From this point, the Japanese economy was fragile and easily influenced, which led to its passiveness in international affairs; and, therefore, it had to accept and suffer the resulting debilitating effects.

All of these factors meant that the increasing exports that intensified competition with the rest of the western world were responsible for the financial collapse in Japan. The rapid development of Japanese export shares on the foreign industrial markets had become a political issue in, for example, the United Kingdom and its colonies, such as India. The paradox formed for various reasons, making the ruling of Japanese militarism inescapable. Japan wanted to industrialize and modernize in order to counterbalance other western countries. After all, due to its lack of resources, Japan could only increase the volume of its imports and exports, which would have inevitably offended the old capitalist nations. If these countries force to block Japan from accessing their needs, Japan's economy would decline. In order to avoid this circumstance, militarism inevitably arose. Only by expanding outwards towards China, which owned enough natural resources, could Japan thrive in the 20th century.

\section{NATIONALIST REVIVAL}

One of the direct results of the great economic challenges that both countries experienced was a revival of nationalist movements. When countries move through periods of economic recession and depression there is a tendency to scapegoat a particular group of people to be accountable for their deplorable conditions. This often results in a blame of foreigners for the high unemployment rate and the retrogressive economy, which, therefore, gradually pushed nationalism to its tip within each country. Nationalism arises as a strategy of within the country as a way for citizens to resist foreign enemies.

This general pattern played out in diverse ways with the rise of Nazism in Germany and militarism in Japan when nationalist ideas were exacerbated by the pressure of foreign powers. One crucial part was the social upheaval and new political movements after WWI led by the cession of German territory ordained in the Treaty of Versailles. According to Article 51, the land of Alsace-Lorraine, obtained by Germany after the Franco-German war in 1871, was again returned to France. The eastern part of Germany, where the fertile farmlands of Posen and the Polish corridor between Germany and East Prussia were situated, were given to Poland [2]. At the request of France, Great Britain, and all victorious nations of World War I, these provisions, which were considered to be humiliating by the Germans, came into effect. As a result, Germany lost 73,485 square kilometers of land, with a population of 7,325,000 [3]. Countries headed by Britain and France aimed to take this opportunity to deprive Germany of 
its ability to develop again wholly. They, however, underestimated the influence of nationalism over the German population. A new system of an ideology built upon Prussian authoritarianism was gradually formed in reaction to the mortifying articles and the incompetent Weimar government.

Along with the loss of territory German citizens also watched the demilitarization in all divisions of the army after WWI. The manufacturing of weapons, ammunition, or other war products may not be carried out in factories or facilities, the existence of which must be recorded and approved by the Governments of the Principal Allied and Associated Powers and the quantity of which they have power [3]. Importation of weapons, ammunitions, and war materials of all sorts into or from Germany was also explicitly forbidden, according to Article 170 [3]. All these measures were done to limit Germany's military power and prevent it from having the ability to challenge the status of other nations in Europe. Article 42, 43, and 44 in the Treaty of Versailles, on the other hand, stipulated that "Germany is forbidden to maintain or construct any fortifications either on the left bank of the Rhine or on the right bank to the west of a line drawn 50 kilometers to the East of the Rhine" [3]. France, who was afraid of another invasion from Germany across the Rhine River, categorized its left bank as a demilitarized zone in order to further weaken Germany. However, French actions had angered the Germans; these treaties of peace, at the cost of German freedom, had not wholly defeated Germany's determination to revive but had only made it worse. Under the incitement of the Nazi government, more and more people had then decided to join the so-called war of revenge (World War II) by Nazi propaganda.

Other sections of the Treaty of Versailles, such as Article 119, announced German's loss of all her overseas rights and titles in consideration of the Principal Allied and the Allied Forces. The loss, after all, turned the attention of extreme nationalists to Eastern Europe: for example, Adolf Hitler and his concept of Lebensraum mentioned in Mein Kampf.

The incident that pushed nationalism to its peak, however, was the Occupation of Ruhr. The Treaty of Versailles "empowered the Allies to impose sanctions should Germany default on the peace terms" [8]. Failures in negotiations and the coal default declared by the Reparation Commission on January 9, 1923, started the occupation act in Düsseldorf and the western Ruhr cities by French and Belgian troops, with British acquiescence. France adamantly promoted its policy. A new French-backed currency was ultimately introduced for the Rhine and the Ruhr. During October 1923, French and Belgian supported an abortive separatist rise in the Rhineland [8]. The Alliance's blockade and restrictions on food decimated the economy in Ruhr as well as its people. Women paid a high price because orderly life had disintegrated, and they suffered frequent abuse by the invading army [8]. "Twenty Germans were said to have been killed, and several French soldiers wounded when a mob at Rapoch attempted to prevent the expulsion of one hundred officials." according to the Anaconda Standard published on February 10, 1923 [9].

Political and social upheaval had started, followed by the food riots in Ruhr and the intimations of collaboration with the occupiers. Domestically, the French occupation accelerated the formation and growing influence of rightwing parties. The conservatives founded a consortium of nationalist associations, the United Patriotic Association of Germany (VVVD), formed in 1922 in response to the disorientation by the defeat in the war [8]. The VVVD achieved its peak in the climate of national resistance and hatred towards the French occupation by promoting measures of uncompromising monarchism, corporatism, and opposition to the Treaty of Versailles [8]. It obtained eventual unity by the late 1920s, as the National Socialist German Workers' Party emerged.

Similar to Germany's experience, the humiliation that Japan encountered during the process of westernization raised internal dissent and nationalist thoughts that eventually called for military expansion. The incident of the Perry Expedition and the signing of the Treaty of Kanagawa precipitated the construction of Japan's modern army and reformation of Japanese society [8]. The Perry Expedition started when Commodore Matthew Perry of the United States arrived at the Edo Bay with four warships. He demanded better treatment of sailors shipwrecked on Japanese islands and a foreign trading relationship with Japan. Six months later, Matthew Perry came again, using his guns and warships to make Japan sign the Treaty of Kanagawa with the U.S. The treaty included twelve articles; each being considered as an insult to the Japanese. Article 2, for instance, forced Japan to open its trading ports for foreigners. Others included proper treatment of the sailors in Article 4 and the freedom of exchanging goods was also discussed in Article 7 [10]. The treaty fully ratified the U.S. government's concern regardless of the sense of nationalism rising in Japan, and it is this sense of desperation to modernize and westernize that led to the future Meiji Restoration in the future.

Another significant factor was the series of diplomatic incidents between Japan and the United States from 1900 to 1920 when the Japanese began to feel discrimination against them. The U.S. - Japanese agreement, concluded in 1894, had granted the Japanese the freedom to immigrate to the United States and share the same privileges as U.S. citizens. In 1906, however, the San Francisco School Board enacted a plan to move Japanese and Chinese students to separate schools [11]. The Japanese government was outraged by the deliberate racial discrimination. From 1907 to 1908 , a series of notes exchanged, known collectively as the Gentlemen's Agreement, ended with the U.S. Government agreeing to pressure the San Francisco authorities to withdraw the measure, and the Japanese government promised to restrict the immigration of laborers to the United States [11]. Ethnic antagonism further escalated, fueled by inflammatory articles in the media. Notwithstanding the efforts to keep peace between the two countries, the 1924 Immigration Restriction Act repealed the resolution. The Alien Land Act of 1913 that "barred Japanese from owning or leasing land for longer than three years" had further adversely affected the U.S. - Japanese relations [11]. In 1915, the Japanese government issued the "Twenty-One Demands" of China, who turned to the United States for support; and so, U.S. officials reacted by claiming they did not accept any negotiation that compromised the Open Door. At the League of Nations conferences in 1919 , Japan and the United States clashed yet again on the request for racial equality. The Treaty of Versailles gave Japan influence over vital German assets in Shandong, which led to an outrage in China. The Shandong issue remained unsolved 
until the Washington Conference was held. On February 4, 1922, through the guidance of the United States, China, and Japan concluded the "Regulations for the Solving of the Shandong Suspended Case." On December 10, 1922, the Chinese government officially took back Qingdao, and Japan withdrew all its troops from Shandong. All rights and interests of Qingdao Customs, Qingdao were successively within the stipulated period withdrawn by the government of the Republic of China in Beijing. The United States' "partiality" had again made Japan feel insulted: while both governments sought to protect their own political and economic interests, territories and resources in Asia could challenge one another.

The Institute of Pacific Relations (IPR) was initially founded to coordinate Japanese-American conflicts. The plan failed, however, and brought a destructive impact on their relations. American internationalists and politicians were aware of the growing nationalist movements in Japan; from their perspective, nationalism was irrational and extreme. East Asian countries, especially Japan and China, after all, "believed the protection and strengthening of the nation were the only reasonable response to Western imperialism" [12]. But for Americans, they had "exacerbated the problem with their habit of ignoring domestic problems while making judgments about other countries" [12]. By the founding of the Institute of Pacific Relation in 1925, the relationship between the United States and Japan had already worsened dramatically due to the General Immigration Act, which banned all Asian immigrants, passed by Congress in 1924. One commentator attacked what he saw as a dangerous cult of Emperor worship, which also represented the trending public opinion by then. In this case, the Japanese were further alienated, and their relationship with the U.S. was in mortal danger. In 1938, Japan had staked out a position of clear opposition to the matter, in which the Japanese Council responded formally in a letter written by Tadao Yamakawa, suggesting the IPR should do "purely academic and strictly objective research" [12].

In reaction to the US and other Western nations 'stance, the letter sent an explicit and rather aggressive message against American attempts to manipulate Japan's internal affairs, though also announcing its aim of occupying East Asia, with its anti-Western ramifications. The IPR was mainly a failure from this perspective. Whoever developed and promoted it forward dichotomized the conceptions of patriotism and reason, whether the country was genuinely irrational or whether the idea that internationalism was felt beyond fair estimation was retained [12].

\section{SOCIAL INFLUENCE AND POLITICAL PROPAGANDA}

The rise of nationalism in both countries during the interwar period developed into a form of patriotism that exerted a large influence upon social beliefs and eventually political movements and parties. Whereas German Nazism arose in a somewhat chaotic and unstable society, imperialist Japan was created from relative stability and at the hands of the Emperor, a longstanding figurehead of Japan. As for Germany, the uneven distribution of wealth intensified social conflicts. Hyperinflation mentioned previously, for instance, widened this inequality. Speculators profited from it: with devalued currencies, the industrialists and landlords who owed money were willing and able to pay their debts [4]. Those who owned property in forms of lands and products or those who had skills were better prepared for the bartering, whereas the middle class suffered most of the loss as a result of hyperinflation, for they had lost all their savings in forms of paper money and banking [4]. During this period, somehow, many towns and cities issued their own emergency money, called the "note geld" in which many carried antiSemitism themes [4].

German anti-Semitic agitator Wilhelm Marr created the word anti-Semitism. In essence, he believed the term was created on the base of "science," rather than on theological beliefs that may have motivated antagonism against Jews in 1879 [13]. Its key ideas that contributed to the rise of Nazism, however, had existed since medieval centuries. In the Black Plague from the mid-14th century, Jews were scapegoated, massacred, and banished from cities and villages for contaminating the water and air [13]. In his letters, Martin Luther vented his wrath against Jewish people for their refusal to convert to Christianity. And for several decades, leftleaning socialist leaders were tempted to create a connection between Jews and "the capitalist enemy," since the long-period exclusion of the Jews from European affairs gave them the ability to dominate trading business and finance later on. Wisdom and knowledge gave wealth and other monetary gains to the Jewish people, yet they had also become a mortal sin. German nationalists that rose in the reign of the Weimar Republic, including the Nazi Party, thus exploited the shared hatred of Jews to gain more influence.

The Barmat Scandal brought domestic anti-Semitism to its peak when the Nazis took the opportunity of provoking social conflicts to create chaos and thereby profiting. The so-called Kurisker Barmat Scandal happened in the first half of 1925 when Reich President Friedrich Ebert was convicted of being manipulated by Ostjuden, Jews from Eastern Europe, with other prominent Social Democrats and leaders of the Center Party, of whom had reportedly utilized their political connections to secure massive loans from the Prussian State Bank through theft and bribery [13]. The arrest of Julius and Henry Barmat, Russian Jews living in Amsterdam and Berlin, had prompted a highly anti-Semitic campaign in which members of the government were also attacked by a coalition of Communism, German Nationalism, and members of the radical political Right. The Barmat Scandal has been considered as the "Panama Canal" for the Weimar Republic, referring to the Panama Scandal in which a group of Jewish financiers was blamed for embezzlement.

Hitler, on the other hand, made clever use of the incident to propagate his political views, especially anti-Semitism. In his autobiographical manifesto Mein Kampf, Hitler voiced his belief that "the state must, therefore, regard its highest task as the preservation and intensification of the race - the fundamental condition of all human cultural development" [14]. The concept of Aryan supremacy was also discussed in the book: to Hitler and his followers, science, art, technology, and inventions were products of a few people and originated from one race, for which the whole culture depends on them [14]. Although the argument sounds completely illogical today, it was inflammatory for some people at that time. Anti- 
Semitism was then derived, and the Jewish people were described as greedy and hideous. Hitler needed an imaginary enemy that could be not only responsible for the domestic soaring prices, massive unemployment, and famine but also able to intimidate the Germans by making them believe that only by obeying the Nazis could they fight their enemies. All the hatred emerged from the incitement of Hitler's propaganda machines: "Wherever in the world we read of attacks against Germany, Jews are their fabricators" [14]. Throughout history, although an imaginary enemy, in reality, may not do anything, the media can still choose to describe them as hysterical figures. Through newspaper reports and analysis, it was the Jewish people who destroyed the land and enslaved their loved ones. Therefore, the importance of dealing with this hypothetical enemy went beyond public power, social welfare, medical care, housing, and other practical issues. All other issues had to make concessions for the "crisis of Jews": All laws needed to be amended for it, all personnel who hindered the achievement of the highest goal had to be dealt with immediately; all industrial and natural resources had to be serving the case. And only in this way could the greatest internal strength be gathered to resist foreign enemies. All the terror, instability, and turbulence human made, or accidental gave the Nazis the excuse to rise, seize power, and move forward in centralizing it.

The flaws in the Weimar Constitution gave the Nazi party opportunities to arise by failing to maintain judicial justice and stability. Article forty-eight granted the Reich president of powers to take necessary measures without the prior consent of the Reichstag under emergency circumstances for restoration and intervention with the aid of the armed forces [15]. The Social Democratic Party of Germany, the ruling party of the Weimar Republic, had tried to use this law frequently to achieve specific political goals. This substantive dictatorship, hence, gave the Nazi party a veritable account, which in turn won more supporters for them. Hitler, moreover, relied on this article after the Reichstag Fire in 1933 to pass the following decrees and acts that limited the freedom in speech, prints, and petition as well as enabled him to acquire the unlimited dictatorial right. Article seventeen and sixty one stipulated that "Every state must have a republican constitution" and "in the case of the larger states one vote shall be assigned for every 700,000 inhabitants" [15]. The system's proportional representation had several defects. First, there was a lack of or even no constituency: the political opinions of parliamentarians often did not reflect the attitudes of regional voters. Some candidates with official capacity often could not enter the parliament. Second, there was no upper limit or lower limit for parliamentary seats, lowering the effectiveness of the Reichstag. In just fourteen years, as many as thirty political parties entered parliament. When these factors were added up, turmoil and chaos in German politics ensued, making the unstable democratic system even more fragile. Article twenty-five gave the president of the Reich rights to dissolve the Reichstag as a symbol of "democracy" [15]. The elections, however, had lost their due seriousness, and democracy had become an "overwhelming" factor. In general, the fundamental structure of the Weimar government was defective by giving the president, the states, and the army too much power, while proportional voting divided and weakened the Reichstag.
The equal uprising of the KPD, the Communist Party of Germany, gave Hitler another way to gain support. Communism, according to the Communist Manifesto, sought for the formation of the bourgeoisie into a group, the abolition of capitalist hegemony, the capture of proletarian political control, and the eventual abolishment of private property [16]. Karl Marx believed that capitalism, as a political and economic superstructure, suppresses human nature and makes people abandon their potential, and wasting their lives in a meaningless hierarchical structure and alienation process. Although some Germans expressed support for Communism, most of them opposed it since they were frightened of the Red Revolution and Bolshevism. The German Communist Party was a mere tool for Bolshevik expansion in 1925 that followed and obeyed the thoughts and demands of Moscow [17]. Many KPD members, however, joined without proper consideration, viewing it as a movement of defiance that could be quickly withdrawn than an assertion of fundamental disagreement or ideology. Contrary to the aspirations of Bolsheviks, the majority of participants of the KPD decided to enter the group as it appeared to provide one of the possibilities for civic involvement in a democratic society [17]. Besides, KPD, a "brawling party" as it had often been depicted in literature, tended to present itself as emphatically peaceful to attract young and violence-prone workers, yet it had increased the growing dissatisfaction among the real Bolsheviks in the party. Under this circumstance, the Wittdorf Affair of 1928 broke out. At that time, KPD secretary Wittorf used several funds and taverns that represented an ordinary worker's annual profit with improper use mostly damaged the public respect for KPD [17]. As for Hitler, his avocation for "the destruction of Marxism in all its shapes and forms" had then won him, supporters [17]. Hitler ingeniously combined the people 's fear of Communism with the hatred of Jews and came upon the following conclusion: Communism, including Marxism, was a Jewish tactic for subjugating Germany and the nation, and regarded Communism as an intellectual and political type of slavery.

Aggressive and illegal means were utilized in order to win voting for the Nazi party, including the Reichstag Fire of 1933, the Reich Fire Decree that followed, and the Enabling Act of 1933. The thought against KPD, Bolsheviks, and communist ideology happened to cater to the ideas of most politicians, capitalists, and the public at the time. According to the final testimony of the Reichstag Fire Trial, "at about 9:00 p.m. on February 27, with the election campaign well underway, a flame burst out. A policeman stationed outside the Reichstag, he saw some flames and a shadowy figure who seemed to be rushing through the building, setting fires [...] At about 9:30, a search party inside the Reichstag came across a man crouching in a small side room. Stripped to the waist, begrimed, sweating, and breathing heavily, he looked almost like a hunted animal. He gave himself up at once; a pass to a local relief shelter identified him as Marinus van der Lubbe, a Dutchman" [18]. As a part of the Dutch Communist Party, he had attended several Nazi meetings in Berlin and had tried to set fire to two other buildings. He was convicted and sentenced to death by the court.

The fire at the Reichstag offered Hitler a perfect chance to remove all Reichstag progressive resistance of the Communists, Socialists, and pacifists. He persuaded 
President Hindenburg to issue the "Decree of the Reich President for the protection of the People and State" that suspended much of the constitutional freedoms promised by the Weimar Republic and increased the power of the Reich over the state governments [18]. Article one, for instance, enabled the regime to detain and execute political rivals without the use of any specific reason, to dismantle political organizations, and to censor publications [19]. The second and third articles of the decree granted the Central Government the right to override and supersede state and local laws [19]. Despite the acts, the Nazi Party was still unable to occupy an absolute majority position in the Reichstag elections of 1933 [19].

Although Hitler was still 31 votes after banning the Communists, he convinced the German Center Party to support his plan. At the Reichstag session at the Kroll Opera House in Berlin on March 23 1933, Hitler argued that the new legislation - the Enabling Act - would not lead to the dissolution of the Reichstag, as he would only utilize his existing constitutional power in crises over the next four years [20]. The combined effect of the two laws, however, was to transform Hitler into a legal dictator and grant him unlimited power to rule over the nation.

In contrast, it was simpler for the Japanese militarist to win support than those of Nazism. If the rise of Nazism can be described as a result created by all unstable factors, domestically or internationally, the shifting political focus to militarism in Japan was a relative peaceful and calm process. The Meiji Constitution was one of the essential steps that allowed the shift of focus to militarism in Japan. The establishment of the Tenno System recognized Shintoism that deified the power of the Emperor as a national religion. The Emperor was honored as the incarnation of God and had divine authority. Although the Meiji Constitution granted religious toleration of subjects, it still mostly maintained the dominance of the nation's Shinto. Rescript and other related provisions, for example, of the Meiji Constitution, were a form of the national Shinto ritual itself "we do hereby, in virtue of the Supreme power: We inherit from Our Imperial Ancestors, promulgate the present immutable fundamental law, for the sake of Our present subjects and their descendants" [21]. Japan's military command and authority were not under the jurisdiction of the Cabinet but the direct control of the emperor. Since the emperor was only the highest commander by name, the country's military power was formed by the gradually formed Marshal's Office and General Staff Headquarters. Articles thirty-three through thirty-five stipulated that the House of Representatives needed to discuss political affairs and legislative work with the conservative aristocracy in the House of Peers; and its power did not hold much administrative power [21]. Therefore, although the Meiji Constitution fulfilled the democratic spirit of European and American countries on the surface, its content still consisted of numerous restrictions to freedom, liberty, and democracy. Article 11 stated that the Marine Corps was directly accountable to the Emperor, implying that the generals of the Marine Army would be able to override the power of the Prime Minister or other political departments to influence the Emperor's decision-making [21].
The biggest flaw in the entire constitution was that the Constitution did not explicitly stipulate how to elect the Prime Minister of the Cabinet, which led to the direct appointment of Ministers over the previous 60 years. For example, in the late Meiji period, the Prime Minister of the Cabinet was usually recommended by the elders to the Emperor. In the Taisho era, due to the decline of the political influence of the Prime Minister and the popularity of the political party, the Prime Minister was elected by the leader of the House majority party. With the growing discontent and conflict in the society "Wag the Dog Syndrome" Japan decided to use force on foreign countries [21]. The act of militarism, therefore, came to dominate. On the eve of the Sino-Japanese War of 1894, for instance, the Meiji government had a series of conflicts with Congress over budget issues, until the following year, when the Qing Dynasty was defeated and surrendered. The Japanese victory of the Sino-Japanese War of 1894 triggered a great sense of national glory in Japan. Because the leaders of party politics could not control the power of the military like their elders and rely on their faction relations, they were helpless to the military's rightwing activists. They could not appoint and dismiss military leaders and could only be passive in action. On the contrary, the military department could completely ignore the decision of the party leader, and any action could only be responsible to the emperor, resulting in the increasingly traumatic situation of the military department.

Thus, after the political assassination in the Taisho era, the upsurge of party politics began to cool down and was replaced by the rise of rightwing activists and the militaristic ideas. The rise of the rightwing originated from two fuses. The first was the Wall Street stock market disaster in the United States in 1929, which triggered a global domino economic disaster. The Japanese economy also entered the Great Depression. The incompetence of political parties prompted people to seek new political rules. One of the rightwing doctrines was to obtain resources through external expansion and restore economic prosperity.

Then came the September 18th Incident of 1931. The Japanese Kanto Army launched a raid in Manchuria, invading the entire territory of Northeast China, and established the Manchuria State. At that time, the Japanese Prime Minister Inu Yoshii was initially expected to resolve the diplomatic crisis in the three eastern provinces by peaceful means. However, his intention was intercepted by the Japanese military, angered the military radicals, and was eventually assassinated by the navy. After the death of Inu Yoshii, Saito's cabinet was controlled by the military leaders, consisting of fifteen people, of which ten were from the military and only five were from political parties. Military politics continued until the end of World War II.

Political propaganda was used differently among Japan and Germany due to the distinctive needs and requirements of each society. The tactic was to pressure the weakest link between the capitalists and working class, the place in which the conflicts often erupted. The Nazis, especially Joseph Goebbels, knew the importance of dramatizing their talk, deeds, and existence through political propaganda to meet their expectations in the Reichstag election. The primary practice is to emphasize good acts: the military spirit and the soldier spirit had been bred into the whole German society for 
centuries. The act of "playing soldier" strengthened the idea of collectivism. Fighting or even dying for the group, from this point, was considered an honorable and respectable act. Secondly, "all-inclusive propaganda is used with the cigarette, candy, gramophone records, stationery, and other articles of consumption" [22]. Third, from the slogan such as "it is the Versailles Treaty and the 'system' it forced upon Germany that has brought all the trouble," Nazis found the unemployed youths, indebted shopkeepers, starving families, and the slum proletarians a target to blame, and an excuse for the loss of World War 1 [22]. Next, propaganda glorified nationalism, evoking a national hatred towards Jewish people, Communist, and Allied Powers, and connecting Nazism with patriotism.

The Nazis also saw despair among middle-class housewives. Therefore, they turned much of their attention to astrology and fortunetelling for consolation and relaxation. "In Hanussen's weekly, the wildest of Nazi dreams, hopes and plans were established as coming and foreseen in the horoscope of von Hindenburg, von Papen, von Schleicher, Hitler, and others" [22]. Large-scale plays were presented from a superstitious perspective, produced by the supernatural department, for instance. Quotes at the time included "the sun is big and is in the division consisting of the three signs of Jupiter (Trigon) the majestic Trigon! All these would be strong signs for Hitler assuming the post of Chancellor and later even higher posts" [22]. Next, by weaving generalizations, delusions, assumptions, and biases around the shared values and activities of men, Nazi propaganda achieved the highest expectations.

As for Japan, "up until the general election of 1924, hometo-home calls had been the principal activity of candidates during campaigns" [23]. Speeches at public meetings were of little significance, while written messaging consisted mostly of letters of endorsement from prominent political members and other powerful backers, which the candidate would send to electors in his area [23]. The first important election after the change became a "Fight of Speech and Writings" since the election law of 1925 prohibited home visits along with individual interviews and telephone calls in response to the longstanding criticism that this type of direct contact often became an occasion for bribery [23]. The Jitsugyo Doshikai introduced the modern trend by selling advertisement space in the Osaka newspapers ahead of the 1924 election. Four years later, Seiyukai and Minseito went on stage better, printing full-page advertisements for their initiatives in all major dailies [23].

The third trend after the general election was the integrated use of different media. Although reports do not say how many copies were distributed, estimates claimed that 27,000 were openly provided to parts of two major mass organizations, the Imperial Reservists Association and the Greater Japan Young Men's Federation [23]. Further versions, as stated in the papers, were available for sale. Emotional appeals tended to triumph above rational argumentation, even in newspaper ads, which were the apparent product of a concerted tactical reform. For illustration, a Seiyukai statement issued in 1932 was distant from the lengthy introduction of policies that had been circulating four years prior. Instead, the party presented voters with a blunt question: "Which do you choose? Boom or depression?" [23].

\section{CONCLUSION}

Overall, similar reasons contributed to the success of rising militarism and Nazism in Japan and Germany: the economic crisis was triggered by a global recession while nationalist movements caused upheaval. Differences still existed, however. Within a relatively peaceful political situation, militarism seized its power in Japan. In contrast, Nazism had to overthrow the previous political structure and traditional values entirely as the result of social disturbance, which also led to their different political propagating methods. Nevertheless, it was a dark age: people pushed extreme parties onto the altar of politics. When governments began to incite the will of the people, and the people began to support government decisions, the two nations embarked on the road of military expansion fueled by nationalism.

During World War II, invasions and resistance movements broke out in various regions of the world, and people's blood and corpses spilled over the land. As a result, the eyes of many people were filled with either despair or tiredness, anger, or sadness. At the war's end, tens of millions of soldiers and civilians worldwide died in the conflict they died of smoked barrels, of mortar shells; they died in the freezing air of Soviet Union, in the hot breeze of the African continent; they died like heroes or cowards; they died for faith with pride or died for nothing in the end. When the fanaticism eventually dissipated, all that remained were the lost souls of people.

\section{REFERENCES}

[1] "Germans Barter for Goods in Response to Hyperinflation, 1923." In Historic World Events. Detroit, MI: Gale, 2012. https://link.gale.com/apps/doc/BT2359070274/WHIC?u=garrisonfor \&sid=WHIC\&xid=ff00c0af.

[2] Knox, Philander C. "Treaty of Versailles." Library of Congress. Last modified 1919. https://www.loc.gov/law/help/us-treaties/bevans/must000002-0043.pdf.

[3] Sally Marks, "The Myths of Reparations," Central European History 11, no. 3 (1978), https://doi.org/10.1017/S0008938900018707.

[4] Hyperinflation.

https://www.johndclare.net/Weimar_hyperinflation.htm.

[5] "East Asia/Southeast Asia: Japan." In CIA World Factbook https://www.cia.gov/library/publications/the-worldfactbook/geos/ja.html.

[6] Masato Shizume, "The Japanese Economy during the Interwar Period: 両大戦間期の日本における恐慌と政策対応 Instability in the Financial System and the Impact of the World Depression," Bank of Japan Review Institute for Monetary and Economic Studies, https://www.boj.or.jp/en/research/wps_rev/rev_2009/data/rev09e02.p df.

[7] Hatase, Mariko. "Devaluation and Exports in Interwar Japan: The Effects of Sharp Depreciation of the Yen in the Early 1930s." MONETARY AND ECONOMIC STUDIES, October 2002 https://www.imes.boj.or.jp/english/publication/mes/2002/me20-35.pdf.

[8] Conan Fischer, "Occupation of Ruhr," last modified October 14, 2016, https://encyclopedia.1914-1918-

online.net/article/ruhr_occupation?version=1.0.

[9] Anaconda Standard (Anaconda, Montana, U.S.), February 10, 1923 Digital file.

[10] Empire of Japan Treaty (Treaty of Kanagawa). Last modified 1854. http://core.ecu.edu/hist/tuckerjo/kanagawa.pdf.

[11] "Japanese-American Relations at the Turn of the Century, 1900-1922." In the Office of the Historian, Foreign Service Institute. https://history.state.gov/milestones/1899-1913/japanese-relations.

[12] Jon Thares Davidann, "'Colossal Illusions': U.S.-Japanese Relations in the Institute of Pacific Relations, 1919-1938," Journal of World History 12, no. 1 (Spring 2001).

[13] Schweitzer, Frederick M. "Anti-Semitism." In Encyclopedia of Genocide and Crimes against Humanity, edited by Dinah L. Shelton, 40-47. Vol. 1. Detroit, MI: Macmillan Reference USA, 2005. 
https://link.gale.com/apps/doc/CX3434600026/WHIC?u=garrisonfor \&sid=WHIC\&xid=a60f6973.

[14] Adolf Hitler, Mein Kampf: The Ford Translation, trans. Michael Ford, 2nd ed. (Camarillo, CA: Elite Minds, 2010), Volume 2 Chapter 2.

[15] Weimar Republic Constitution. Last modified August 1919. http://germanhistorydocs.ghidc.org/pdf/eng/ghi_wr_weimarconstitution_Eng.pdf.

[16] Karl Marx, Friedrich Engels, and Martin Puchner, The Communist Manifesto and Other Writings (New York: Barnes \& Noble, 2005).

[17] Bert Hoppe, "Iron Revolutionaries and Salon Socialists Bolsheviks and German Communists in the 1920s and 1930s," Kritika 10, no. 3 (Summer 2009): https://link.gale.com/apps/doc/A251856410/WHIC?u=garrisonfor\&si $\mathrm{d}=$ WHIC\&xid=28fca903.

[18] "The Reichstag Fire Trial: 1933." In Great World Trials. Detroit, MI: Gale, 1994.

https://link.gale.com/apps/doc/BT2307000046/WHIC?u=garrisonfor $\&$ sid $=$ WHIC \& $x i d=305223 \mathrm{a} 3$

[19] "Decree of the Reich President for the Protection of the People and State ('Reichstag Fire Decree')." German History in Documents. Las modified February 1933. http://germanhistorydocs.ghidc.org/pdf/eng/English\%203_5.pdf.
[20] "The Enabling Act of 1933 ('Gesetz zur Behebung der Not von Volk und Reich')." German History in Documents. Last modified March 1933. http://germanhistorydocs.ghi-dc.org/pdf/eng/English5.pdf.

[21] "Meiji Constitution." In Gale World History Online Collection. Detroit, MI: Gale, 2014 https://link.gale.com/apps/doc/ZCKBQZ374196138/WHIC?u=garriso nfor\&sid=WHIC\&xid=164aaca3.

[22] Nelson, Roger B. "Hitler's Propaganda Machine." In Government, Politics, and Protest: Essential Primary Sources, edited by K. Lee Lerner, Brenda Wilmoth Lerner, and Adrienne Wilmoth Lerner, 264 70. Detroit, MI: Gale, 2006. https://link.gale.com/apps/doc/CX2687500109/WHIC?u=garrisonfor \&sid=WHIC\&xid=e9c7f712

[23] Revelant, Andrea. "Learning How to Appeal to the Masses: Election Campaigns in Interwar Japan." Archiv Orientalni 79, no. 2. Digital file. https://search.proquest.com/researchlibraryprep/docview/1353326116 /7F543AC659334817PQ/1?accountid=606

[24] Geyer, Martin H. "Contested Narratives of the Weimar Republic: The Case of the 'Kutisker-Barmat-Scandal." Weimar Republics/Weimar Subjects: Rethinking the Political Culture of Germany in the 1920s, 211-35. Digital file. 